\title{
"Carve-Outs" from the Workers' Compensation System
}

\section{David I. Levine Frank Neuhauser Jeffrey S. Petersen}

\begin{abstract}
Decentralized regulation has become increasingly important in many areas; examples range from school vouchers to workplace safety committees to alternative dispute resolution procedures replacing courts. Consistent with this trend, in 1993 California permitted construction unions and employers to "carve out" their own workers' compensation system. This study examines California's early experience with carve-outs by analyzing two case studies, a survey of all carve-outs in existence during the study period, and preliminary data on costs and dispute frequency at one carve-out. Overall, carve-outs do not appear to harm employees, and sometimes they help. At the same time, data analysis of one carve-out showed it had no effect on costs and dispute rates. Moreover, the low involvement of union officials and the many issues that overlap other parts of workplace regulation raise concerns about decentralizing workers' compensation. Lessons can be learned for other spheres of regulation. (C) 2002 by the Association for Public Policy Analysis and Management.
\end{abstract}

\section{INTRODUCTION}

Decentralized self-regulation is replacing command-and-control regulations in many spheres of government intervention around the globe. Examples include school vouchers in many nations, food and transportation safety in the United States, equal employment opportunity regulation in the United Kingdom and United States, and pollution regulation in Indonesia. ${ }^{1}$ Decentralization holds the promise of increasing flexibility and experimentation while lowering dispute rates and compliance costs. Decentralization also raises the risks of organizations evading their responsibility under the law (see references cited in footnote 1). This study examines one innovative form of decentralized self-regulation-workers' compensation in the California construction industry. In California, and in 11 other states, construction unions and management can bargain to create an alternative workers' compensation system (a "carve-out") that replaces much of the state run system.

\footnotetext{
${ }^{1}$ On employment see U.S. Department of Labor (1994) and Levine (1997); on food safety see Michael (1996); on equal employment opportunity see Dickens (1999); and on pollution see Pargal and Wheeler (1995).

Manuscript received November 2000; revise and resubmit recommended January 2001; second revision April 2001; accepted January 2002

Journal of Policy Analysis and Management, Vol. 21, No. 3, 467-483 (2002)

(C) 2002 by the Association for Public Policy Analysis and Management

Published by Wiley Periodicals, Inc. Published online in Wiley InterScience (www.interscience.wiley.com) DOI: $10.1002 /$ pam.10055
} 


\section{8 / “Carve-Outs" from the Workers' Compensation System}

This article evaluates how decentralized union-management negotiation worked in the first years of these carve-outs, beginning with background information and then summarizing two case studies and a survey of all California carve-outs. In addition, quantitative results are presented on how one carve-out affected dispute rates and costs. ${ }^{2}$

\section{CARVE-OUTS}

Throughout the late 1980s and early 1990s, employers' cost for workers' compensation in California escalated, peaking at $\$ 17.5$ billion in 1993. At the same time, workers continued to receive low benefits; for example, benefits equaled only about 40 percent of wages lost from injuries resulting in permanent partial disabilities (Peterson, Reville, and Kagenoff-Stern, 1997). Even these benefits were often received only after prolonged dispute. Median time to resolve permanent disability claims was 3 years and the cost of settling disputes exceeded 1 billion dollars a year. The system was extremely complicated, with innumerable steps and thousands of pages of complex regulations.

Widespread frustration led to a series of reforms in 1993. One set of reforms attempted to replicate an innovative experiment in Massachusetts, where Bechtel and the Pioneer Valley Building and Construction Trades Council formed a carve-out through a collective bargaining agreement governing a single large construction project. The Bechtel experience was important because workers' compensation costs per hour fell from $\$ 2.21$ to $\$ 0.98$ (comparing 8 months pre- vs. post-carve-out). This decline was due to fewer lost time claims, which fell from 11 claims in the 8 months before the carve-out to 2 claims in the following 8 months, even as overtime employment increased slightly (Bechtel Construction Co., 1997, personal communication). ${ }^{3}$

The carve-out statute in California, passed in 1993, gives unions and employers considerable leeway to negotiate an alternative to the highly regulated workers' compensation system. Unions and employers can bargain over most of the important elements of workers' compensation, including medical treatment, medical-legal evaluation, vocational rehabilitation, dispute resolution, and increases (but not decreases) to indemnity benefits.

Unions were engaged in all phases of the carve-out process in California construction. The president of the California Building and Construction Trades Unions played an influential role in writing the initial carve-out legislation. All of the carve-outs' collective bargaining agreements established a board of trustees composed of an equal number of union and employer trustees to govern the carve-out. The trustees were responsible for interpreting the collective bargaining agreement as it applied to ongoing issues related to the carve-out. The carve-outs had the capability for continuous improvement, as the union can, and often did, renegotiate the terms of the carve-out if it appeared to harm union members.

Proponents of carve-outs expected substantial savings on medical treatment by allowing the parties to negotiate extended employer control over the choice of physi-

\footnotetext{
${ }^{2}$ Prior research on carve-outs has been primarily based on anecdotes, problems arising in hypothetical cases (e.g., Moscowitz and Van Bourg, 1995; Ozurovich, 1995), or problematic research designs (California Division of Workers' Compensation, 1996, 1997).

${ }^{3}$ Bechtel indicated in discussions with the authors that they had been unsuccessful at recreating the success of the Pioneer Valley project at other large construction projects in subsequent years. However, none of these later projects simultaneously included all of the characteristics of the Pioneer Valley project.
} 
“Carve-Outs" from the Workers' Compensation System / 469

cian providers. Workers would be protected because the provider list is negotiated under collective bargaining. Ideally, both unions and management will agree to bar high-cost physicians (many of whom may be operating on the margins of fraud) as well as physicians who under-provide useful services.

Medical treatment accounts for 40 to 45 percent of all workers' compensation benefit costs in California. Employers pay all medical costs and control the choice of a provider for the first 30 days of treatment, after which the worker has the right to select a different doctor. The state attempts to control costs by imposing fee schedules and adopting treatment guidelines. In spite of this extensive regulatory effort, treatment costs are 50 to 100 percent higher under workers' compensation than under an employer-provided health insurance (Baker and Kruger, 1995; Neuhauser et al., 2000; Zaidman, 1990).

Proponents of carve-outs also expected these programs to reduce disputes and shorten resolution time by allowing employers and unions to negotiate alternate dispute resolution (ADR) procedures. These procedures always began with an ombudsperson who was expected to attempt to resolve disputes quickly. Disputes the ombudsperson could not resolve proceeded to mediation and then to arbitration. These ADR procedures were expected to be more efficient than the state-run statutory system, which involves a lengthy and legalistic procedure for dispute resolution that confuses many workers (Sum and Stock, 1997). Dispute resolution in the state system also costs employees and employers almost one-third of all disputed medical and indemnity benefits. Moreover, claim resolution in the statutory system is a long process-in California, half of all permanent disability claims are unresolved 3 years after the injury, and 20 percent remained unresolved 5 years after.

A controversial component of most carve-out agreements, including the two case studies discussed below, was the exclusion of lawyers from participation at the ombudsperson and mediation stages of the dispute process. If mediation failed, the case could go to arbitration. The joint labor-management committees appointed the mediators and arbitrators who, in practice, were all former workers' compensation judges. In the statutory system, workers are represented by a lawyer in 80 percent of injuries resulting in permanent disability (WCIRB, 1994-1996). Many of the employers and union leaders who participated in carve-outs believed that heavy reliance on attorneys and the corresponding excessive disputes was a main cause of the high cost of litigation and delays in claim resolution. Disputes often require forensic doctors to report on issues related to legal questions such as whether the condition is work related, the extent of permanent disability, and the share of the impairment due to prior injuries. Carve-outs allowed the parties to negotiate a limited list of medical evaluators whose opinions both sides respected. At the time of 1993 reforms, most serious claims involved multiple forensic reports from competing doctors, often chosen by lawyers for their conservative or liberal interpretation. Cost of these reports exceeded $\$ 500$ million per year in the early 1990s. Numerous statutory and regulatory measures had been adopted in an effort to limit the incentive for parties to choose doctors that evaluated in a partisan manner. Much of the complexity of these regulations was in place to protect injured workers, particularly unrepresented workers who are typically less informed than insurers on the selection of favorable evaluating doctors.

Carve-outs had to meet two requirements: they could not diminish scheduled indemnity benefits to injured workers, and they had to make the final step of their dispute resolution system an appeal to the Workers' Compensation Appeals Board for reconsideration. The board is also the last administrative law step of the standard system. Parties may appeal a Workers' Compensation Appeals Board ruling to the State Courts of Appeal. 


\section{0 / “Carve-Outs" from the Workers' Compensation System}

Early analyses of California's carve-outs found fewer litigated disputes, less participation by attorneys, and lower benefit payments per injury (California Division of Workers' Compensation, 1996, 1997). The apparent savings encouraged many employers. At the same time, some union leaders and plaintiff's attorneys expressed concern that savings on medical costs arose from reducing the quality of care by restricting treatment to an agreed list of medical providers (Moscowitz and Van Bourg, 1995). Even more critically, opponents contended that injured carve-out employees received lower benefits because they had less access to lawyers (California Applicants Attorneys Association, 1997, personal communication).

\section{OBJECTIVES, DATA, AND METHODS}

This study began in 1997 when eight carve-outs existed in California. Employers who participated in carve-outs during 1997 employed slightly more than 10 million personhours and spent $\$ 242$ million in wages.

Multiple methods were used. Case studies were conducted of the two largest carve-outs operating during the time of our study: one involving the National Electrical Contractors Association (NECA) and the International Brotherhood of Electrical Workers (IBEW), and the second involving the Eastside Reservoir Project. The NECA-IBEW carve-out signed up all 23 of the IBEW locals in California and 250 of the approximately 500 unionized contractors belonging to NECA. The Eastside Reservoir Project involved the Metropolitan Water District of Southern California (the project owner), 17 unions, and roughly 300 contractors and subcontractors.

For each case study, the union representatives, employers, program administrators, ombudsperson, and service providers were interviewed. Also interviewed were injured workers, carefully selected with the assistance of the ombudsperson-each worker's dispute at least required the intervention of the ombudsperson. No worker was interviewed who did not have a dispute. The focus on these respondents was part of a strategy of testing the limits of carve-outs-an efficient research strategy for qualitative research (Eisenhardt, 1989).

Overall, 81 persons involved in workers' compensation or carve-outs in California were interviewed, and some of them were interviewed multiple times. Also interviewed were each of the six ombudspersons (some ombudspersons worked at more than one carve-out) and many key respondents were interviewed repeatedly. Most interviews were taped and transcribed. In addition, all of the collective bargaining agreements governing carve-outs were reviewed.

For the NECA-IBEW carve-out the effect of the carve-out on claims rates, costs, and dispute frequencies was estimated. This carve-out was chosen because of its size and the opportunity it provided to compare very similar employers (unionized electrical contractors) inside and outside the carve-out, both sets of whom hired a relatively homogenous group of workers. The Workers' Compensation Insurance Rating Bureau (WCIRB) of California provided data on four categories of costs: medical, indemnity (i.e., wage replacement), legal, and medical-legal (i.e., the cost of medical evaluations of legal issues). Medical and indemnity costs were available as both paid and incurred, where incurred costs equal paid costs plus the insurance companies' estimates of future obligations. Payroll was available by class code (approximately equal to occupation). For electricians the focus was on class codes covering journeymen and apprentice electrician. Employer costs were compared for workers' compensation before (policy years 1992-1993) and after (policy years 1994-1995) the establishment of the carve-out in 1994. 
During the study period workers' compensation claims generally declined. This secular trend implies that simply analyzing carve-outs by comparing results before and after the carve-out was implemented would be misleading. Some NECA members joined the carve-out and others did not, which allowed us to do a comparison of carve-out members with non-carve-out members. Thus, a double difference was performed, comparing the rates of change at carve-out members and non-members.

In addition, at employers who joined the carve-out, only electricians were covered by the carve-out while other workers at the firm were not. Thus, two control groups could be constructed: electricians at non-carve-out firms, and non-electricians at carveout firms. A double differences analysis examined rates of change of carve-out participants vs. non-participants. This study design controls for both fixed attributes of an employer that might influence its decision to join the carve-out, as well as secular trends affecting all electricians in the state. All employees in the first contrast were unionized electricians working as NECA members and covered by NECA-IBEW contracts. Thus, wages, training, and many other job characteristics were nearly identical. All employees in the second contrast were employed at the same employer. The weakness of the second control group is that job duties differed; for example, the non-electricians at carve-out employers included office workers. The strength of this within-employer comparison is that all characteristics of the employer that affected all employees (e.g., a cost-cutting program or safety program) should have affected both the treatment group of carve-out electricians and the second control group of non-electricians at the same employers. ${ }^{4}$

\section{National Electrical Contractors Association-International Brotherhood of Electrical Workers}

The statewide NECA-IBEW collective bargaining agreement established a carve-out involving electrical contractors and unionized electricians in California. At interview time, NECA included more than 500 employers in California. Each employer had the option of joining the carve-out and approximately half opted in. All locals of the International Brotherhood of Electrical Workers in California had the option to join or opt-out of the arrangement and all opted to join. The carve-out covered approximately 10,000 of the 38,000 union electricians in California.

The carve-out agreement created the NECA-IBEW Workers' Compensation Trust Fund to pay for the administration of the alternative dispute resolution program. The employers paid 2 percent of their workers' compensation insurance premium, about $\$ 60$ per full-time employee per year. The carve-out agreement also created a committee with equal employer and union representation to supervise the carve-out and to hire an administrator and an ombudsperson staff.

Workers who were covered by the carve-out and sustained an injury on the job received all medical and hospital services from an extensive list of medical service providers. This list was sufficiently broad to include an employee's regular physician. The union and management also negotiated an exclusive list of medical-legal and vocational rehabilitation providers.

The NECA-IBEW carve-out also had a Labor-Management Safety and Health Committee with three members appointed by the employers' association and three mem-

\footnotetext{
${ }^{4}$ We have no data on individual employees except those that filed a workers' compensation claim. For these workers we can identify their occupational code (for example, journeyman electrician vs. apprentice electrician), age, and wage. Thus, instead of running regressions, we used a simple difference-in-differences analysis and weighted the sample to reflect the pre-carve-out distribution of occupations. Results were unchanged with regressions.
} 


\section{2 / “Carve-Outs" from the Workers' Compensation System}

bers appointed by the union. The Committee advised the parties on the implementation of safety programs. The safety committee was a statutory requirement for most construction firms to participate in a carve-out.

\section{East Side Reservoir Project}

The Eastside Reservoir Project (ESRP) was a Metropolitan Water District of Southern California effort to construct an enormous reservoir near Hemet, California. It was a $\$ 2$ billion project, the largest construction project in the western United States, that took 5 years to complete.

The ESRP carve-out involved a single project owner negotiating an agreement with multiple unions. Although almost 300 contractors and subcontractors were involved on the project, the carve-out was simplified because the project owner arranged workers' compensation (and many other forms of insurance) through an owner-controlled insurance plan that covered all contractors and subcontractors. The policy had a significant element of self-insurance in the form of a very large deductible.

The ESRP carve-out emerged as a result of a belief shared by the national and state construction trades unions and by the Metropolitan Water District that the construction of this reservoir was the ideal situation for a "project labor agreement" - an agreement binding on all of the unions and contractors. The ESRP project labor agreement included a no-strike clause and the carve-out among several other components.

The main interest of the owner in negotiating a project labor agreement was incorporating the no-strike clause. Each union had a separate contract with renegotiation dates that were staggered over the duration of the project. Therefore, the primary goal was to avoid any disruptions in the construction schedule. However, the owner representatives indicated that a no-strike clause by itself was insufficient to compel the owner to negotiate a project labor agreement. The deciding factor was the project owner's expectation that the carve-out would reduce workers' compensation costs.

The union desired a project labor agreement including "carve-out" provisions to increase members' employment. Workers can only be covered by a carve-out if they are members of a union that collectively bargains an agreement. Under the negotiated agreement, non-union contractors were effectively limited to 15 percent non-union labor. In addition, all non-union workers were required to join one of the signatory unions for the duration of work on the project. In short, to a first approximation, the bargaining exchanged the owner's agreement (on behalf of its many contractors) to hire almost entirely union labor for the union's agreement not to strike and to negotiate restrictions on delivery of workers' compensation benefits. All parties hoped that reducing the role of lawyers and the delays of the statutory system would reduce costs and increase the speed of return to work. The project labor agreement established a Joint Workers' Compensation Committee to oversee and advise all parties. The committee could designate a list of authorized health care professionals. Negotiations led to an extensive list of medical providers, including an occupational medical network proposed by the employer and the preferred provider network of each of the local building trades' Health and Welfare Trusts.

\section{Issues in Dispute Resolution}

Two issues arose repeatedly in the case studies, the survey of the ombudspersons, and discussions with stakeholders in the workers' compensation community; namely, the role of the ombudsperson and the role of lawyers. 
"Carve-Outs" from the Workers' Compensation System / 473

The ombudsperson played a key role in the carve-outs studied, but that role was substantially different from the traditional role played by ombudspersons. In traditional ADR processes, standard disputes in a workplace go up the managerial chain of command, while the ombudsperson provides an alternative avenue for dispute resolution. Within carve-outs, by contrast, the ombudsperson was the first step in resolving any dispute. Thus, injured workers contacted the ombudsperson (often by phone) when checks were late, when they did not understand whether their injury was eligible for workers' compensation, when they thought the insurer's offer was too low, and for many other reasons.

Another departure from the traditional role of ombudsperson was the focus on information and proactive intervention within carve-outs. All of the six ombudspersons working in California said they spend more of their time providing information to injured workers than they did resolving disputes. Most ombudspersons within carveouts contact all workers with disabling injuries immediately after injury, although some waited for injured employees to have a problem and then contact them. The centrality of information dissemination as a key function of the ombudsperson was corroborated when the ombudspersons were asked to list their three most important functions - the only function all listed among their most important was the delivery of information. In the regulated system this informational role is typically filled by the applicant's attorney. Since it was the goal of carve-out proponents to replace the role of the attorney with the ombudsperson, the timeliness and quality of information within carve-outs is important.

Most of the carve-outs did not allow lawyers to be present during an injured worker's consultation with the ombudsperson or at mediation. These provisions did not preclude workers from hiring attorneys to advise them during the early stages of dispute resolution. The ombudspersons and insurers claimed to have made this distinction clearly to injured workers. Moreover, the letters we reviewed from two of the insurers were clear on the issue.

However, employees' perception of access to lawyers was lower than ombudspersons' claims of informing workers and the letters sent by insurers. Virtually all of the injured workers interviewed reported that they were told they could not have an attorney. Apparently, the message often was not communicated successfully.

An important motive for establishing carve-outs was to reduce employees' confusion about the workers' compensation system, particularly relating to dispute resolution (Sum and Stock, 1997). Unfortunately, because carve-outs were new, they often created new forms of confusion (in addition to the confusion about whether employees could hire lawyers noted above). Several employees and union officials provided examples of other sources of confusion with the new institutions. Although employers circulated documents about the carve-out at time of hire, employees appeared unaware of the carve-out at the time of their injury. After the injury they sometimes received conflicting information from colleagues, union officials, or lawyers. In addition, many officials of the union locals were likewise uninformed.

Workers covered by a union that has collectively bargained for a carve-out must participate in the ADR process. Several of the workers interviewed expressed frustration because they thought the state-run system might have provided them a better outcome. These workers could ultimately have their cases appealed to the state-run system, but only after completing the ADR process. Some said this would be too much to handle and instead settled their cases at mediation or arbitration. Having a case go through the entire ADR process and then dealing with the state-run system was considered too emotionally draining. In addition, if an outcome in ADR carries 


\section{4 / “Carve-Outs” from the Workers' Compensation System}

weight in the statutory system, it may be less likely that a lawyer will take a workers' case in the statutory system if the outcome was negative at ADR.

Carve-outs were designed to deal with delivery of medical and indemnity benefits on workers' compensation claims and the settlement of disputes over these benefits. However, many workers' compensation claims-particularly the most serious - can involve other issues. This blurred boundary of "the" workers' compensation system highlights the challenges of negotiating alternatives to state regulation. For example, wrongful termination after an injury, claims of serious and willful violations of safety protections, and claims against third parties can be problematic within the structure of a carve-out. Substantial penalties are applied for these violations that cannot, by statute, be indemnified through workers' compensation insurance.

These claims put the ombudsperson in a conflict of interest. On the one hand, the employer directly or indirectly hired the ombudsperson, who typically serves at the will of the employer or joint committee. Employment on future projects may depend on employers' perceptions on the current project. On the other hand, the ombudsperson has an obligation to help an injured worker sue the employer for a serious violation.

Claims against third parties are also complex. In these claims someone besides the employer contributed to an injury and, thus, can be sued in civil court. For example, in some cases the third party might be an equipment maker. In such cases the ombudspersons face little conflict of interest in informing an employee that he or she can sue the equipment maker. At the same time, on some large projects, such as the Eastside Reservoir, the project owner largely self-insures the liability costs (including third-party claims) of the subcontractors. Thus, if the third party is a subcontractor, the project owner pays the penalties. When the ombudsperson's employment (either at this site or at future sites) depends on satisfying the project owner, such thirdparty claims present a conflict of interest.

In general, the ombudspersons preferred to move serious and willful violations and wrongful termination claims to the statutory system. However, this solution could lead to problems of forum shopping if the entire claim moves to the statutory system. Alternatively, it can lead to delays and extra hearings if the case must be heard once in the carve-out ADR and once in the statutory system.

Finally, a number of claims, particularly in the construction industry involve multiple employers. All employers with financial exposure on these cumulative injury claims may not be participants in the carve-out. Potential conflicts of interest arise when ombudspersons, mediators, or arbitrators are responsible for ruling on apportionment of financial responsibility between groups of employers inside and outside the carve-out.

Given these various tensions, it is too early to evaluate how well the ombudsperson function operates and how successfully it can replace many of the traditional roles of attorneys and litigation. Some preliminary evidence is available from the few injured workers interviewed. As noted, these injured workers were selected because their claims required at least intervention by the ombudsperson. Nearly all injured workers praised the ombudsperson in attempting to resolve their disputes and in subsequently advising them during mediation or arbitration.

\section{QUANTITATIVE ANALYSIS OF THE EFFECTS OF THE NECA-IBEW CARVE-OUT}

Preliminary data collected on outcomes at the NECA-IBEW carve-out included safety, workers' compensation costs and benefits, and dispute rates.

When items concerned medical and indemnity costs, both paid data and incurred data (that is, the amount the insurance company has set aside for future payments) were analyzed. Because it can take years to settle a workers' compensation claim, 
“Carve-Outs" from the Workers' Compensation System / 475

each form of cost data has strengths and weaknesses. In the first few years after an injury, paid data will show higher costs for any system that closes claims more rapidly_a misleading impression if the slower system will eventually have the same or higher costs. Incurred data involve insurance company estimates of future payments. Because carve-outs are novel institutions, insurers' forecast of future costs may have been biased, although the sign of the bias is unclear. Because a high proportion of costs are found in a few claims that take many years to settle, the preliminary nature of the cost data makes any results tentative.

\section{Safety}

Reported claims rates for electricians in the NECA-IBEW carve-out were 26 percent lower in the two years after the start of the carve-out than in the two years before its introduction (Table 1). This rate of improvement was slightly, but not statistically significantly, better than the 23 percent reduction for electricians at the non-carveout employers. Employees who were not electricians but worked for electrical employers inside of the carve-out had an 18 percent decline in claims rates. Thus, preliminary data at NECA-IBEW did not find substantially more rapid declines in reported claims rates for electricians within the carve-out than in comparison groups. ${ }^{5}$

Table 1. Number of claims per $\$ 1$ million exposure (all reported claims).

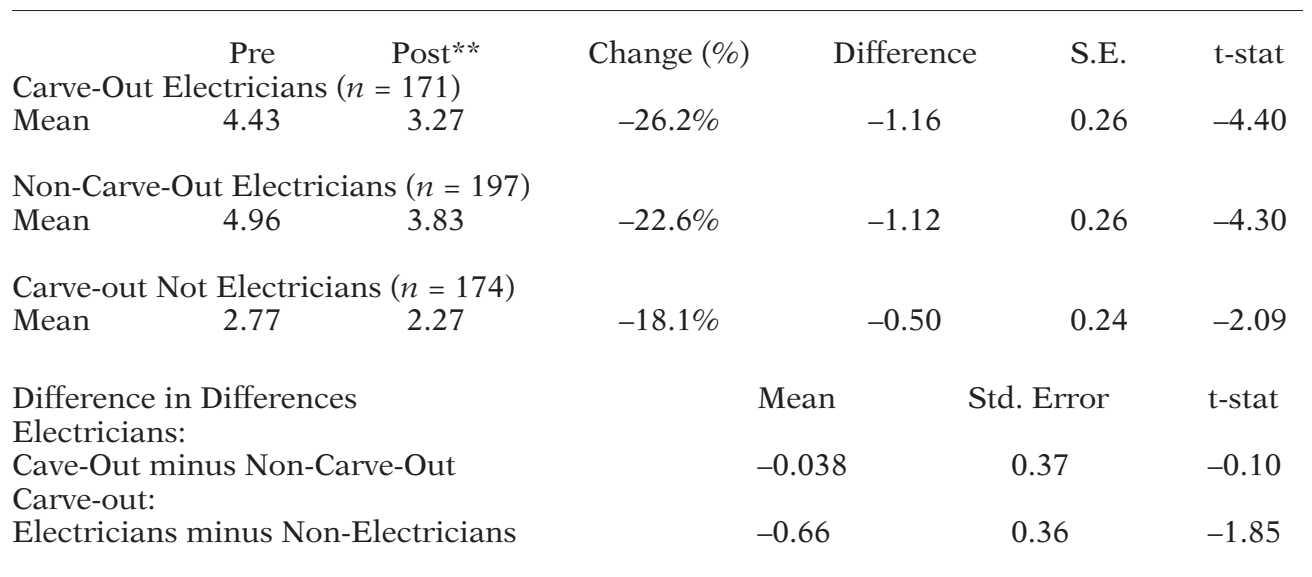

Notes: $n=$ number of separate entities (either establishments or employers, as indicated by Bureau Numbers) reporting data in both the pre- (1992 and/or 1993) and post- (1994 and/or 1995) periods. Figures for the post-carve-out period (1994 and 1995 policy years) are weighted to reflect the proportion of journeymen and apprentices working in the pre-carve-out period (1992 and 1993 policy years).

\footnotetext{
${ }^{5}$ As a check on the validity of simple ex-post comparisons, safety records of carve-out participants and non-participants were compared before the carve-out. Some, but not consistent, evidence indicates that employers opting into the carve-out were safer than non-carve-out electrical contractors (results available on request). Claim frequency relative to exposure was lower for all claims, for claims for disabling injuries, and for claims for permanent disability at carve-out employers. In the other direction, premiums were significantly higher and experience modification levels (insurance companies' summary of past claims costs) were similar. To the extent that carve-out employers were systematically different before joining the carve-out, valid comparisons among carve-out and non-carve-out participants require the double difference approach used here.
} 


\section{6 / “Carve-Outs" from the Workers' Compensation System}

This quantitative result is consistent with the qualitative findings of the case study. All the employers had active safety programs at the worksite level both before and after joining the carve-out. In contrast, participants indicated that operation of the additional safety committee created specifically to meet the requirements of the carve-out was perfunctory at the carve-out level.

\section{Workers' Compensation Costs}

Table 2 reports incurred indemnity and medical costs for the carve-out electricians and the two comparison groups. The basic result is that no trends differed significantly between the carve-out electricians and the two control groups. Specifically, incurred indemnity benefits for injuries to electricians within the carve-out fell more rapidly than benefits for electricians outside the carve-out after the program was started. However, indemnity benefits to workers who were employed by carve-out employers but not covered by the carve-out fell even more substantially than the payments to carve-out electricians. Similar results occurred for medical costs among the different groups of workers pre and post carve-out. None of the double difference results were statistically significant.

\section{Dispute Rates}

To analyze changes in dispute rates, the percentage of claims was calculated with mandatory settlement conferences in the statutory system (the first stage of formal dispute resolution) and compared with the number of mediations in the carve-out

Table 2. Difference in differences comparison of workers' compensation costs.

\begin{tabular}{|c|c|c|c|c|c|c|}
\hline $\begin{array}{l}\text { Electricians (at carve- } \\
\text { out firms) }\end{array}$ & Pre C-O & Post C-O & Change $(\%)$ & Difference & S.E. & t-stat \\
\hline Medical incurred & $\$ 10,153$ & $\$ 9,711$ & $-4.3 \%$ & $-\$ 441$ & 1811 & -0.24 \\
\hline $\begin{array}{l}\text { Indemnity incurred } \\
\text { Electricians (outside } \\
\text { carve-out) }\end{array}$ & $\$ 14,491$ & $\$ 11,584$ & $-20.1 \%$ & $-\$ 2,907$ & 2565 & -1.13 \\
\hline Medical incurred & $\$ 9,800$ & $\$ 9,874$ & $0.8 \%$ & $\$ 74$ & 1858 & 0.04 \\
\hline $\begin{array}{l}\text { Indemnity incurred } \\
\text { Non-electricians (at } \\
\text { carve-out firms) }\end{array}$ & $\$ 15,074$ & $\$ 14,030$ & $-6.9 \%$ & $-\$ 1,044$ & 2650 & -0.39 \\
\hline Medical incurred & $\$ 8,190$ & $\$ 5,216$ & $-36.3 \%$ & $-\$ 2.974$ & 1222 & -2.43 \\
\hline $\begin{array}{l}\text { Total indemnity } \\
\text { incurred }\end{array}$ & $\$ 12,498$ & $\$ 9,642$ & $-22.8 \%$ & $\$ 2,844$ & 2341 & -1.21 \\
\hline \multirow{2}{*}{\multicolumn{4}{|c|}{$\begin{array}{l}\text { Differences in Differences } \quad \text { Mean Std. Error } \\
\text { Electricians: carve-out firms minus non-carve-out firms }\end{array}$}} & t-stat & & \\
\hline & & & & & & \\
\hline & & & 2594 & -0.19 & & \\
\hline Total indemnity incurred & & $-\$ 1,863$ & 3688 & -0.50 & & \\
\hline \multicolumn{7}{|c|}{ Within carve-out firms: electricians minus non-electricians } \\
\hline Medical incurred & & $\$ 2,533$ & 2185 & 1.15 & & \\
\hline Total indemnity incurred & & $-\$ 63$ & 3743 & -0.01 & & \\
\hline
\end{tabular}

Note: All figures are per $\$ 1$ million exposure (with adjustments for changes in occupational mix). 
(the first stage of formal dispute resolution in the ADR system). Also compared were the rates of hearings in the statutory system (the second stage of formal dispute resolution) and with the number of arbitrations in the carve-out (the second stage of formal dispute resolution in the ADR system) (Table 3). A number of issues make this analysis preliminary. Most importantly, settlement conferences are not mediations, and hearings are not arbitrations. In addition, carve-outs may define disputes differently. Only 21 formal dispute processes were analyzed for carve-out electricians and 36 for non-carve-out electricians in the post carve-out period. Finally, the immaturity of the data, and the fact that data were analyzed from only one carve-out, limit the generalizability of the findings.

With these cautions in mind, dispute rates at the first stage were not lower for carve-out electricians than for comparison groups in the statutory system. Carve-out electricians and non-carve-out electricians both had stable rates of first-stage settlement conferences and mediations, both pre- and post-carve-out (about 7 percent of serious injuries). Carve-out non-electricians had far fewer mandatory settlement conferences (the first stage of dispute resolution in the statutory system) after the carveout was introduced, but the source of this change is not obvious. In contrast, the NECA-IBEW carve-out had no arbitrations, while, in the comparison groups in the statutory system, 6 to 10 percent of claims went to hearings. This result is consistent with the hypothesis that mediation is a successful form of ADR.

At the same time, this result is also consistent with the hypothesis that carve-out employees, because they lack access to attorneys, do not appeal cases they might win. The NECA-IBEW carve-out had 19 percent of employees with serious disability claims represented by an attorney, significantly lower than the 32 percent rate for electricians outside carve-outs and for non-electricians at carve-out employers. As the rates of representation were similar before the introduction of the carve-out, this gap is the only one where the double difference is statistically significant $(p<.05$ comparing changes of electricians at carve-out and non-carve-out employers).

Table 3. Use of formal dispute resolution mechanisms per serious injury.

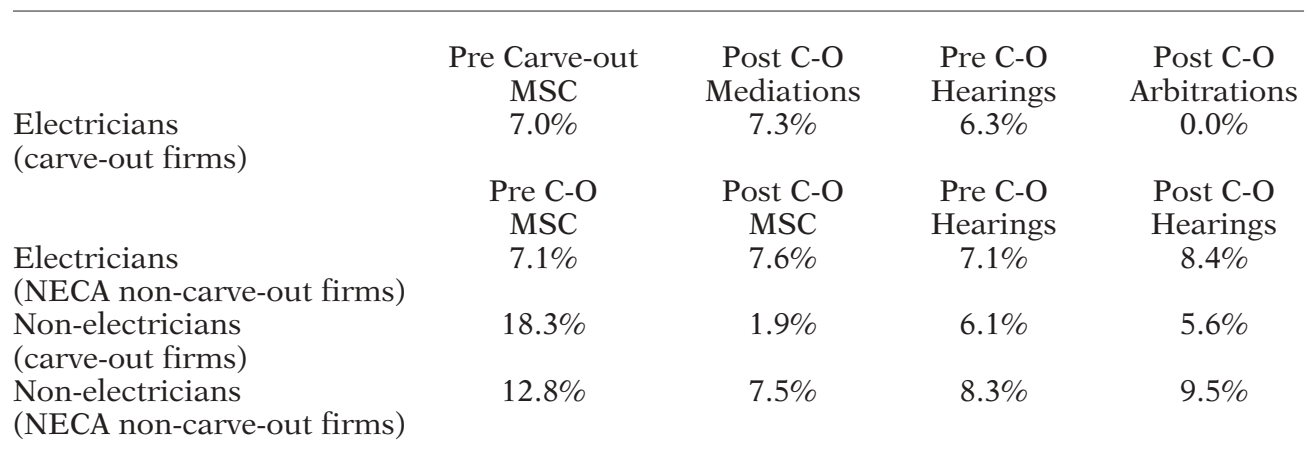

These data involve individually reported claims that also included the Social Security Number of the injured worker, allowing matching to Workers' Compensation Appeals Board databases. MSC = Mandatory Settlement Conferences, the first stage of formal dispute resolution in the statutory system. Hearings are the second stage of the formal dispute resolution in the statutory system. Bold figures refer to the carve-out electricians. 


\section{8 / “Carve-Outs" from the Workers' Compensation System}

\section{Robustness Checks}

Some of the results above are presented per claim (Table 3 ) and others per million dollar payroll (Table 2, roughly per 20 full-time equivalent electricians). Because claims rates per hour worked had similar trends in the carve-out and in its comparison groups, changing the base for the comparisons above never had a meaningful effect on the results.

Table 2 presents results for incurred costs (insurer's estimates of eventual costs). In results presented in a longer report (Levine et al., 1999), where changes were analyzed in paid amounts (controlling for time since injury), results were similar. One concern is that with lower rates of representation, fewer claims receive permanent disability ratings. In fact, this ratio remained roughly constant in the treatment and control groups (results available on request).

Consistent with the stability of relative claims rates and costs per claim, trends in workers' compensation insurance premiums were virtually identical at carve-out and non-carve-out employers. In contrast, in some states insurers specified a discount for participating in a carve-out.

\section{Discussion of NECA-IBEW Carve-out Results}

The evidence for any effect of this carve-out on safety is weak. Claim frequency relative to exposure declined slightly more rapidly at carve-out employers and this effect was more pronounced for more serious injuries. While none of these comparisons was statistically significant, the sign of the differences was consistent with modest improvements in safety. However, reduced reporting of claims could give the same result. What is clear is that declines in the frequency of claims were large for all groups of employees for the years under study. Because the workers' compensation system went through massive changes in California in the mid-1990s, failure to use a control group would lead to a serious overestimation of the carveouts' effects on safety.

There is no evidence that carve-outs reduced medical or indemnity costs or benefits. Incurred medical and indemnity benefits costs (equal to paid costs plus insurers' estimates of future claim costs) as a percentage of payroll declined for almost all subgroups. The rate of decline in incurred costs for electricians covered by the carveout always fell between those of non-carve-out electricians and non-electricians within carve-out firms. Moreover, no differences were statistically significant. Comparisons of changes in paid data (not reported here) also provided no support for early expectations that carve-outs would reduce costs. Similarly, the time between injury and return to work as measured by the number of weeks of temporary total disability paid did not decline more quickly for injured workers within carve-outs.

Thus, on the positive side, there is no evidence that this carve-out reduced employees' benefits. On the negative side, because benefit payments represent the majority of the cost of workers' compensation, there is no evidence that this carve-out reduced employers' costs.

To some extent the failure of cost reduction may be due to carve-outs' lack of use of the tools at their disposal. Carve-outs provide a natural model for integrating 24hour medical care. This model ensures employees a choice of physician, including their own. It also may improve unions' and employers' incentives to pick high-quality medical doctors, as the preferred provider organization of medical doctors is used for both industrial and other care. Another carve-out evaluation of an almost identical population of firms and workers (union electrical contractors in New York City), 
but without a control group, argued that medical costs fell 12 to 25 percent when employers negotiated reduced rates for directing all occupational injuries to a single managed care network (Borba and Parry, 2000).

Cost reductions were most anticipated in the arena of dispute resolution, where the new dispute resolution procedures were most different from the state system. In fact, total legal and medical-legal costs did not decline more rapidly for claims by electricians within carve-outs than for the two control groups. Increases in defense legal costs cancelled out any advantages of lower medical-legal and applicant legal costs. In the carve-out, as in the state system, injured workers who hired an attorney paid 12 to 18 percent of indemnity payments to the attorney. At the same time, because indemnity benefits per claim were similar in the carve-out and control groups, the reduction in the portion of cases represented by attorneys within carve-outs may have slightly increased the average benefits (net of legal expenses) received by injured workers.

Legal costs are to some extent driven by the level of dispute. No evidence indicates that the introduction of the ADR process, including the ombudsperson, has reduced dispute frequency. Strong assumptions are required to compare the incidence of disputes between the ADR process and the statutory system. However, there are no big changes in the frequency with which formal dispute processes in each system are used (comparing mediations in the carve-out with the first-stage process of the statutory system, Table 3). Contrary to conclusions drawn in early reports (California Division of Workers' Compensation 1996, 1997), disputes are not eliminated; instead, formal dispute mechanisms are infrequent in either system.

\section{CONCLUSIONS}

No evidence indicates that carve-outs harmed construction workers in California. Proponents of carve-outs hoped they would greatly reduce dispute rates and costs. Opponents of carve-outs feared that lower dispute rates would largely indicate a lack of benefits and access to representation. No evidence found in this study supports either the proponents' or the opponents' claim. Dispute rates were not substantially different in carve-outs and the statutory system. In the one carve-out with preliminary data, rates of change of the number of claims, costs per claim, benefits, and dispute frequency were roughly equivalent inside and outside of the carve-out.

The promise of carve-outs is that employers and unions can create a better alternative than the state-run system. A presumption is that both sides will know if the new system is meeting their members' needs. In fact, few union leaders followed the progress of the carve-out. Often the union representatives at the local level were unaware of the how the carve-out operated, and none of the injured workers interviewed praised their union representatives for assisting them during the ADR process. As far as could be determined, no union leader contacted injured employees about the effectiveness of the new system. Union leaders' lack of information raises the risk that decentralization may harm workers. If carve-outs are to flourish, local union officials must educate themselves about the carve-outs' effects.

Carve-outs can help create a health care system that is easier for workers to understand. For example, injured workers in most California carve-outs can use their regular doctors. At the same time, the carve-outs confused most participants. For example, at the time of their injury, none of the injured workers interviewed knew they were covered by an alternative workers' compensation system called a "carve-out," nor the rules under which the new system operated. Moreover, workers (and some lawyers) were often unsure when workers could use lawyers. 
The lessons from California, though preliminary, are important because carve-outs in workers' compensation have been established (in some form) in a dozen states, and may soon begin to expand outside construction. In addition, innovations developed in carve-outs are being introduced into the statutory system. For example, both Texas and Florida have adopted the proactive ombudsperson approach, first developed at Pioneer Valley and the Eastside Reservoir projects, on a statewide basis for all loss-time injuries.

The carve-out system raised several issues with respect to lawyers' institutional incentives. To the extent that lawyers, restricted as to representation, take on only the more difficult cases, the carve-outs may not generate enough revenue to justify the cost of attorney time within these new structures. Conversely, if the ADR system handles simple claims that lawyers normally decide to get involved in, the amount of lawyers fees in these simple cases could outweigh their value to injured workers. To date, carve-outs have not negotiated alternative arrangements for attorney contingency fees. In theory, the arbitrator sets the lawyer's fees. In practice, the ombudsman reviews the fees and the lawyer is paid on a contingency basis identical to the statutory system. Nevertheless, the system might operate more efficiently if more options were available for fee arrangements.

\section{Broader Implications}

Carve-outs in California show some of the promise of decentralized regulation and some of the pitfalls. The promise is found in areas such as rapid experimentation with alternatives to medical benefit delivery and judicial processes. The pitfalls include reduction in the legal protections offered by the regulated system and changes in the balance of power when legal dispute arise.

One important lesson from carve-outs that may apply to other decentralized regulatory schemes is the importance of a representative of those affected. Within carveouts, unions have played a crucial role in ensuring that carve-outs do not diminish workers' rights. Union leaders have far better information about the carve-out system than do individual employees. Thus, they are better able to identify (or evaluate employers' claims to have identified) procedures in the statutory system that impede quality of care, are burdensome for employees, or that slow the resolution of disputes without corresponding gains for employees.

The protection provided by unions is particularly important because carve-outs have often traded reductions in some employees' rights for benefits the unions evidently perceived as more important. For example, the several carve-outs with the most restrictions on medical treatment provide for 10 percent increased indemnity payments for certain permanent disabilities. The ESRP carve-out negotiated dispute resolution procedures that restricted attorney participation and limited restrictions on medical providers. In turn, the building trades negotiated nearly exclusive union labor on the largest construction project in California. In New York City, the electrical workers negotiated a carve-out with a very restricted medical provider arrangement attractive to employers while offering injured workers 40 percent increases in temporary disability benefits. None of these arrangements are allowed within the statutory system.

These instances of negotiated agreements suggest that there are substantial opportunities for gains for both parties from negotiated arrangements. Similarly, unionmanagement negotiations often diverge from one-size-fits-all regulations in areas such as over-time rules and drug testing. Workers' compensation is particularly likely to have large gains from negotiations because unions and employers can avoid rules 
that were established largely to benefit other parties such as attorneys, medical providers, and insurers.

In contrast to carve-outs, nonunion employers can write mandatory employment arbitration clauses in the United States unilaterally. Typically only the employer is a repeat player in the arbitration system and the arbitrator typically or always awards damages that are less than what employees might gain in court (U.S. Department of Labor, 1994). Even with a union negotiating the agreement, carve-outs raise some concerns about employee protection in the absence of ongoing oversight of the processes. Thus, the experience of carve-outs, not surprisingly, gives little encouragement to think that dispute resolution systems designed unilaterally by the employer will protect employees' rights. ${ }^{6}$

In considering other spheres of workplace regulation, decentralization may also be able to build on new or existing institutions that can help monitor formerly regulated entities. Polluters can have their plans approved by local governments and citizens' groups; schools that receive vouchers can have their strategic plans and performance approved by parent groups, and so forth. Although this decentralized governance will not solve all problems, it can play a useful role in creating accountability to replace command-and-control regulations.

One important lesson carve-outs can take from the environmental arena is that public release of data can improve accountability. Merely releasing data on pollution emissions from a factory sometimes reduces emissions (Foster, 1998). Apparently, the combination of peer pressure from other polluters (particularly those who fear increased regulation), fear of political retribution from those affected, and the desire to appear proactive to regulators, citizens, and legislators often provides meaningful incentives to reduce pollution. The corresponding lesson for carve-outs is that public release of injury rates, benefit levels, and the other data (such as those analyzed in this study) could be beneficial. If the data support the effectiveness of carve-outs, the data could reassure proponents. When problems arose, unions would see the problem more rapidly and be in a position to make improvements. Employees' knowledge of the problems would increase union leaders' incentives to make changes. If the data persistently showed carve-outs were harmful to employees or companies, opponents of carve-outs could easily document the problems.

Thus, it often makes sense to couple decentralized self-regulation with requirements for public release of performance data. The government has a role in creating (perhaps in partnership with employers and unions) standardized formats for data release so that the data can be compared over time and across workplaces. ${ }^{7}$ When data are in a common format to permit benchmarking over time and compared to similar others, employers and unions will have an easier time identifying weaknesses and finding out if proposed changes have the desired effects. Because common trends hit much of a sector, it is important to combine both before-after comparisons and a carefully chosen control group. In closing, in carve-outs, as in charter schools, food safety, pollution self-regulation, or in other forms of decentralized self-regulation, monitoring results and documenting what is working and what is not can be essential to gain the fruits of experimentation and innovation.

\footnotetext{
${ }^{6}$ Levine (1997) and Kochan and Osterman (1994, pp. 205-207) describe how nonunion workplaces might set up employee committees to provide oversight into decentralized regulatory schemes such as arbitration after potentially unjust or discriminatory dismissals, as well as other spheres of regulation including safety and health, employee involvement, and hours of work.

${ }^{7}$ The Workers' Compensation Insurance Rating Bureau already performs much of this function in the workers' compensation arena in California.
} 


\section{2 / “Carve-Outs” from the Workers' Compensation System}

This article draws on a longer study (Levine et al., 1999), with Cristian Echeverria and Richard Reuben. The authors are grateful to the study's respondents, advisory board, and Christine Baker, Executive Officer, CHSWC. We appreciate funding from the California Commission on Health and Safety and Workers' Compensation. This article represents the views of the authors and does not reflect the views of the General Accounting Office or the CHSWC.

DAVID I. LEVINE is an Associate Professor at the Haas School of Business, University of California, Berkeley.

FRANK NEUHAUSER is a Project Director at the Survey Research Center, University of California, Berkeley.

JEFFREY S. PETERSEN is a Senior Economist at the U.S. General Accounting Office.

\section{REFERENCES}

Baker, L.C., \& Krueger, A.B. (1995). Medical costs in workers' compensation insurance. Journal of Health Economics, 14, 531-549.

Bechtel Construction Co. (1997). Telephone conversation with authors regarding experience at Pioneer Valley.

Biddle, J. (1998). Estimation and analysis of long term wage losses and wage replacement rates of Washington state workers compensation claimants. Draft. Michigan State University, East Lansing MI.

Borba, P.S., \& Parry, T. (2000). An evaluation of the comprehensive and organized managed care program: Final Report. New York: Robert Wood Johnson Foundation and The Joint Industry Board of the Electrical Industry.

Bok, D., \& Dunlop, J. (1970). Labor and the American community. New York: Basic Books.

CDWC [California Division of Workers Compensation]. (1996). Annual report to the Legislature on carve-outs. Sacramento, CA: CDWC.

CDWC [California Division of Workers Compensation]. (1997). Annual report to the Legislature on carve-outs. Sacramento, CA: CDWC.

Dickens, L. (1999). Beyond the business case: A three-pronged approach to equality action. Human Resource Management Journal, 9(1), 9-19.

Eisenhardt, K. (1989). Building theories from case study research. Academy of Management Review, 14(4), 532-550.

Foster, A. (1998). TRI emissions decline. Chemical Week, 160(25), 73-76.

Gilmer v. Interstate/Johnson Lane Corp. 500 U.S. 20 (1991).

Kochan, T.A., \& Osterman, P. (1994), The mutual gains enterprise: Forging a winning partnership among labor, management, and government. Boston: Harvard Business School Press.

Levine, D.I. (1997). Reinventing regulation: Letting employees and employers solve their own problems. California Management Review, 39(4), 98-117.

Levine, D., Neuhauser, F., Reuben, R., Petersen, J., \& Echeverria, J. (1999). Carve-outs in workers' compensation: An analysis of experience in the california construction industry. Sacramento, CA: Commission on Health and Safety and Workers' Compensation.

Michael, D.C. (1996), Cooperative implementation of federal regulations. Yale Journal on Regulation, 13(2), 535-601. 


\section{“Carve-Outs" from the Workers' Compensation System / 483}

Moscowitz, E., \& Van Bourg, V. (1995). Carve-outs and the privatization of workers compensation in collective bargaining agreements. Syracuse Law Review, 46(1), 1-60.

Neuhauser, F., Swedlow, A., Gardner, L., \& Edelestein, E. (2000). Pharmaceutical costs in workers' compensation. Report for the Commission on Health and Safety and Workers' Compensation. San Francisco: California Department of Industrial Relations.

The Ombudsman Association (1985). Code of ethics, The ombudsman handbook. http:// web.mit.edu/negotiation/toa/TOAcoe.html

Ozurovich, M. (1995). Pitfalls in collective bargaining can cause serious harm to injured workers and their unions. In The 1996 Workers' Compensation Yearbook ( pp. 164-168). Horsham, PA: LRP Publications.

Pargal, S., \& Wheeler, D. (1995). Informal regulation of industrial pollution in developing countries: Evidence from Indonesia. Washington, DC: World Bank.

Peterson, M., Reville, R., \& Kaganoff-Stern, R. (1997). Compensating permanent workplace injuries. Santa Monica, CA: RAND, Institute for Civil Justice.

Sum, J., \& Stock, L. (1997). Navigating the workers compensation system. Berkeley: University of California.

U.S. Department of Labor. (1994). Commission on the future of worker-management relations-final report. Washington, DC: DOL.

WCIRB [Workers' Compensation Insurance Rating Bureau] (1996, 1997, 1998). Annual report: Workers compensation losses and expenses. Sacramento, CA: WCIRB.

WCIRB [Workers' Compensation Insurance Rating Bureau] (1994-96). Survey of permanent disability claims. San Francisco: WCIRB.

WCIRB [Workers' Compensation Insurance Rating Bureau]. (1994). Workers compensation unit statistical plan. California Workers Compensation Insurance Rating Bureau. San Francisco: WICRB.

Zaidman, B. (1990). Industrial strength medicine: A comparison of workers' compensation and Blue Cross health care in Minnesota. Minneapolis: Minnesota Department of Labor and Industry. 